\section{Internationalization and Global Tension: Lessons from History}

\section{Philip G. Altbach and Hans de Wit}

Philip G. Altbach is research professor and founding director of the Center for International Higher Education at Boston College. E-mail: altbach@bc.edu. Hans de Wit is incoming director of the Center for International Higher Education at Boston College. He continues as director of the Centre for Higher Education Internationalization at the Università Cattolica del Sacro Cuore in Milan. E-mail: J.w.m.de.wit@ hva.nl.

A $t$ the start of the year 2015, after a year of increased political and military tension growing in several parts of the world, including Europe, as well as the fundamentalist attacks in Paris, it is relevant to look at its implications for higher education. The current global climate will inevitably affect international higher education. Increased nationalist, religious, and ideological conflicts challenge the original ideas of international cooperation and exchange in higher education as promoters of peace and mutual understanding and of global engagement. Since the end of the Cold War, we have not been used to this type of tension and turmoil on a global scale. What lessons can we learn from the past in how to act and react in this new environment?

\section{The War to End All Wars}

In medieval times one could speak of a kind of European higher education space, similar to the current one, with mobile scholars and students and a common language-Latin. Universities in the I8th and Igth centuries for the most part became less international as they adopted national languages, sometimes even prohibited study abroad, and focused on national priorities. One can speak of a nationalization and de-Europeanization of higher education in that period.

The end of World War I brought a burst of internationalism. It is worth looking at the internationalization of the past century, because it helped to shape contemporary realities. In the wake of the trauma of World War I, there was a strong belief that the academic community could help build international solidarity and contribute to peace building. A century after the start of the Great War, it is particularly relevant to note the role and ultimate failure of academe in these idealistic efforts.

Europe emerged from World War I, deeply traumatized. Intellectuals and academics on all sides wanted to build solidarity among the European nations as a contribution to peace. Most were horrified that the academic com- munities on all sides had been so easily drawn into fervent nationalism at the beginning of the conflict, easily giving up the veneer of Enlightenment ideals.

The creation of organizations-such as the Institute of International Education (IIE) in the United States in I9I9, the German Academic Exchange Service (Deutscher Akademischer Austauschdienst or DAAD) in Germany in I925, and the British Council in the United Kingdom in I934are examples of political initiatives to stimulate peace and mutual understanding under the umbrella of the League of Nations. These efforts ultimately failed to stem the rise of fascism and Nazism in Europe or Japanese militarism in the Far East. Again, the goals of peace and cooperation were trumped by negative political forces. The most dramatic failure was in Nazi Germany, where the universities participated in Nazi ultranationalism.

\section{A Truly Global Conflagration and Its Aftermath}

Those who lived through World War I could not imagine a similar conflagration - but just 2I years later, World War II broke out. When the war came to an end in I945, a wave of idealism again arose, this time accompanied by the establishment of the United Nations, signaling a commitment to both global security and development. The dissolution of colonial empires also created new realities for higher education in the emerging Third World. Again, higher education cooperation was identified as a means of fostering the development of mutual understanding, and modest exchange programs were established or strengthened, the Fulbright Program being the most dramatic example.

\section{Since the end of the Cold War, we have not been used to this type of tension and turmoil on a global scale.}

In Europe, mobility of students and staff from the former colonial empires to western Europe were the main focus of international higher education activities, but they were rather fragmented and limited. At the national level, at least in Europe and North America, international cooperation and exchange were included as minor activities in bilateral agreements between nations and in development cooperation programs, driven by political rationales. Academic institutions were, in general, passive partners in these programs. 


\section{The Cold War and the Politicization of International- IZATION}

Higher education, as well as cultural and intellectual life generally, became pawns as well as important fronts in the ideological struggles of the period. The era of "good feeling" lasted just a few years, as the struggle between the Soviet Bloc and the West started to develop as early as I946-lasting until the collapse of the Soviet Union in I989. Ideology and power politics were very much part of the Cold War, with the struggle between communism and capitalism, as well as the political contest between the great powers at the center.

Influenced by the Cold War, ideology more than idealism set the agenda in international education, especially between the United States and the Soviet Union. Europe was not much affected since the Third World was the battlefield of international educational cooperation-and struggle: continuing dominance of Western models and systems of higher education, the influence of the English language, the impact of foreign training, the dominance of Western scientific products, ideas, and structures. In other words, neocolonial and Western higher education hegemony were linked to much of international higher education relations during this period. The Soviet Union, for its part, was similarly engaged in expanding its influence. In Europe, the Iron Curtain that divided eastern and central Europe from the west prevented all but the most rudimentary higher education cooperation.

\section{Will we see again a de-Europeanization and nationalization of higher education in Europe emerging.}

Only in the I970s, when western Europe had sufficiently recovered from the impact of World War II and initiated its integration process, did a new type of academic cooperation and exchange emerge that was more focused on strengthening European cooperation and exchange within the countries of the emerging European Union. A modest warming in east-west relations opened doors for academic cooperation to some extent.

Western academic foreign policy, as in the case of the Soviet Union, was also directly linked to Cold War priorities. The former colonial powers - the United Kingdom, France, and to some extent the Netherlands-sought to maintain their influence in their former colonies through an array of scholarship programs, university collaborations, and other schemes. These initiatives also competed directly with the
Soviet Union.

The United States, as the counterweight to the Soviet Union in the Cold War, developed active and far-reaching higher education "soft power" initiatives, such as the Fulbright Program, established in 1946, the National Defense Education Act of 1958 (a direct reaction to the launch the year before of Sputnik I by the Soviet Union), and Title VI of the Higher Education Act of I960 intended to stimulate the development of area studies and foreign language centers as well as programs for international studies and international affairs. Many academic partnership programs, funded through the US Agency for International Development and other organizations, linked American universities with those in many developing countries. These initiatives have to be seen in the context of attempts by the United States to become the leader of the noncommunist world in its Cold War with the Soviet Union.

\section{After the Cold War: Increased International Coopera- TION AND EXCHANGE}

In the I980s, the first signs of increased academic cooperation between central and eastern Europe and western Europe as well as with the United States became manifest. Still, academic cooperation was mainly a political issue and little institutional and personal autonomy was possible. Only after the fall of the Iron Curtain at the end of the I980s, did international cooperation in higher education increase rapidly. Both the European Commission and national governments developed programs to enhance the quality of the sector and stimulate cooperation and exchange. The Transnational European Mobility Program for University Studies scheme (TEMPUS) of the European Community, established in I990 for Hungary and Poland, extended to the other central and eastern European countries over the years. An important example of a national initiative is CEEPUS, a program of the Austrian government. These initiatives formed the basis, not only for the inclusion of these countries in the regular European programs like the Framework Programs for Research and Development and ERASMUS, but also can be seen as a testing ground for the integration of these countries in the European Union. Without question, the impressive array of European Unionsponsored exchange, research, and collaboration programs, both for the "core" EU community and a wider European audience, were related to the broader political and economic goals of the European Union.

\section{The Combination of Politics and International Higher EDUCATION}

Will we see again a de-Europeanization and nationalization of higher education in Europe emerging, in the light of greater criticism of European integration, the growth of 
nationalist populist movements, and tensions between Russia and western Europe and the United States?

In the 2oth century, politics and global ideological struggles dominated the international agenda worldwide. Academic cooperation and exchange have been in many cases, including during the Cold War, the main relations between nations: they continued to take place and even were stimulated so as to pave the way for further contacts. We have to learn from these lessons. International higher education is substantially different from earlier historical periods, as well as from the Cold War. Its scope is also different, with increasing political and academic power influences from other regions of the world, especially Asia. But, even though we should be realistic that international cooperation and exchange are not guarantees for peace and mutual understanding, they continue to be essential mechanisms for keeping communication open and dialogue active. Will the increasingly widespread global conflicts-based on religious fundamentalism, resurgent nationalism, and other challenges-harm the impressive strides that have been made in international higher education cooperation?

This is a shortened version of an essay published in the Journal of Studies in International Education, Vol. I9, No. I, 2015 .

\section{Perspectives on Global Uni- versity Networks}

\section{ROBIN MIDDLEHURST}

Robin Middlehurst is professor at Kingston University, UK. E-mail: r.middlehurst@kingston.ac.uk.

For centuries, higher education has been an internaTtionally connected sector, as scholars have sought to exchange ideas and gain new knowledge. However, such connectivity appears to be reaching new heights, doubtless aided by the ability to connect physically and virtually, but not entirely explained by this. Kris Olds of the University of Wisconsin-Madison, discussing the "seemingly endless thicket of associations, networks, consortia and alliances," argues that we are witnessing a process of denationalization as institutions reframe the scope of their vision, structures, and strategies beyond the national scale. Contrastingly, an analysis of key moments in internationalization from the late I9th to early 2ist centuries finds approaches to internationalization to "denationalize" the university usually do not succeed (or not for long). So why are global networks proliferating and institutional efforts to reach out beyond national borders doomed to failure?

Collaborative historical research across Europe, Asia, Australia, and North and South America, undertaken by scholars within the Worldwide University Network, identifies the development of international consortia and networks as a response to major historical-structural changes in higher education. Universities have joined forces to meet new expectations and solve problems "on an ever-widening scale." They have done this in the light of fluctuating enrollments and funding resources associated with economic booms and busts; new modes of transportation and communication facilitating mobility-among students, scholars, and knowledge itself; increasing demands for applied science, technical expertise, and commercial innovation; and ideological reconfigurations accompanying regime changes. These challenges still resonate as drivers for establishing global networks, but there are also new ones.

Competitive pressures are encouraging institutions and countries to seek competitive advantage through collaboration. The coveted goods of "global reputation" and "world-class status" lead toward rankings, positioning, branding, and reputation management. In the 2Ist century, when the power and influence of global media are ubiquitous, this driver may be stronger than in the past, supported and extended through new social and mobile technologies. Associating with others that are successful, well resourced, or powerful is assumed to bring added value, both in substance and reflected glory. Being invited to join an exclusive network-(such as the League of European Research Universities or Universitas 2I) - signals mutual recognition and a perceived hallmark of quality in the global research hierarchy. For other institutions in search of global partners, factors beyond the "scholarship of discovery" are important signifiers of differentiation and distinctiveness in a crowded marketplace of networks.

\section{Diversity of Global Networks}

Global networks are not just proliferating among institutions; they also cross sectors to engage new partners and leverage partnership assets to achieve benefits for businesses, citizens, and universities. "Triple helix" innovation systems are one example where traditionally separated innovation sources have come together-product development in industry, policymaking in government, and creation and dissemination of knowledge in academia - to facilitate development of new organizational designs, new knowledge, products, and services. A new bridge between Denmark and Sweden helped create the Oresund University Network, opening new research areas and educational possibilities. However, the original network of II universities has shrunk 